Myth and Narrative in International Politics 

Berit Bliesemann de Guevara

Editor

\section{Myth and Narrative in International Politics}

Interpretive Approaches to the Study of IR 


\section{Editor}

Berit Bliesemann de Guevara

Aberystwyth University

United Kingdom

ISBN 978-1-137-53751-5

ISBN 978-1-137-53752-2 (eBook)

DOI $10.1057 / 978-1-137-53752-2$

Library of Congress Control Number: 2016941887

(C) The Editor(s) (if applicable) and The Author(s) 2016

The author(s) has/have asserted their right(s) to be identified as the author(s) of this work in accordance with the Copyright, Designs and Patents Act 1988.

This work is subject to copyright. All rights are solely and exclusively licensed by the Publisher, whether the whole or part of the material is concerned, specifically the rights of translation, reprinting, reuse of illustrations, recitation, broadcasting, reproduction on microfilms or in any other physical way, and transmission or information storage and retrieval, electronic adaptation, computer software, or by similar or dissimilar methodology now known or hereafter developed.

The use of general descriptive names, registered names, trademarks, service marks, etc. in this publication does not imply, even in the absence of a specific statement, that such names are exempt from the relevant protective laws and regulations and therefore free for general use. The publisher, the authors and the editors are safe to assume that the advice and information in this book are believed to be true and accurate at the date of publication. Neither the publisher nor the authors or the editors give a warranty, express or implied, with respect to the material contained herein or for any errors or omissions that may have been made.

Cover illustration: (C) AF Fotografie / Alamy Stock Photo

Printed on acid-free paper

This Palgrave Macmillan imprint is published by Springer Nature The registered company is Macmillan Publishers Ltd. London. 


\section{FOREWORD}

Academic studies-international relations (IR), security studies, political science, public policy studies, and other social sciences-are fully taken up with articulating things, ideas, events, and so on in words. Even the renewed attention to the material aspects of the social world and visual methods for studying them has not-and cannot-displace our engagement with spoken and written language as the medium through which we communicate. Such verbalisation requires that knowing and its communication be made explicit. And yet in that focus on the explicit rendering of acts, events, ideas, thoughts, experiences, and so on another dimension of human life is disappeared: tacit knowledge and its place in human affairs.

Both the concept of tacit knowledge and Michael Polanyi's (1966) exploration of it, which are central to this realm of inquiry, remain underutilised resources in analysing the social world and, in particular, its political dimensions. So the notion that we might communicate with one another through silences perhaps seems odd, or even an oxymoron. But this is, as I have argued elsewhere and as the chapters in this book attest, precisely what political, organisational, societal, and what might be called theoretical myths enable.

Not everything worth studying is rendered explicit, in words. Legislators, other state actors, and community and social movement leaders know this. Studying such phenomena also has methodological-that is, both ontological and epistemological—implications. As Polanyi (1967, 306) put it: 
The fact that we can possess knowledge that is unspoken is of course a common-place and so is the fact that we must know something yet unspoken before we can express it in words. It has been taken for granted in the philosophical analysis of language in earlier centuries, but modern positivism has tried to ignore it, on the grounds that tacit knowledge was not accessible to objective observation. The present theory of meaning [...] assigns a firm place to the inarticulate meaning of experience and shows that it is the foundation of all explicit meaning.

In collective settings such as communities, polities, and organisations, the public sharing of some ideas may become taboo when sufficient consensus has not (yet) been established to support such articulation. And yet, such ideas can still be known-tacitly, and knowledge is capable of being shared, by being communicated 'tacitly'. That ideas can be communicated through tacit means underlies the concept of 'dog-whistling' in politics (e.g. Safire 2008; Haney-López 2014): a way of communicating to particular population groups while bypassing others for whom those ideas counter widely held values and norms, such that their explicit expression would incur cost of one sort or another (e.g. public sanction, derision, loss of face, etc.).

One of the key modes for the tacit communication of tacitly known ideas may usefully be called myths. As found in polities, organisations, or societies more broadly, such myths work to divert attention from what cannot, or should not, be said-if one wishes to preserve the illusion of commonality, of unity, and of collective peace. Myths are framing devices; they direct attention to certain features of their focus, while diverting it from other features. Myths block further inquiry, redirecting attention from expressions that might pose danger to the collective, because they challenge accepted views, towards things that are perceived to be more palatable, less threatening. Myths can be used to 'explain' states' origins, for example, when these are contested, or to account for organisations' operations in problematic situations. Myths can certainly be created for strategic purposes. Still, organisational and policy myths are not always intentionally designed with some strategy in mind, but emerge through less consciously explicit, intersubjective processes as people engage problematic situations. An example from my research illustrates this.

During a field study of the Israel Corporation for Community Centers (ICCC; matnassim in Hebrew), I found the Executive Director repeating, at the close of the annual meeting of all agency staff, the question, 
'What are our goals?' That made sense in the first few years, I thought; but why would he still need to ask it in year 10? Wouldn't-shouldn'tan organisation know its goals after a decade of operations? I came to see this as an organisational myth: the ICCC had been created to implement certain national policies concerning immigrant integration, through largely non-formal educational programmes; yet the structural problems of 'absorbing' immigrants and the limited resources the ICCC had been given constrained their ability to demonstrate achievement of this policy goal. Paradoxically, the ritual of asking that question, annually, in the setting of that meeting, at its high point, effectively blocked further inquiry into the impossibility of the organisation achieving its mandate under the circumstances at hand (Yanow 1992, 1996; Chap. 7).

Another dimension of myths - the indeterminacy of their meaning - is illustrated, inadvertently, in another part of my work. While teaching in The Netherlands in 1994, a series of experiences opened my eyes to the extent to which the state's Jews lived, still, in a sort of hiding from their Christian and secular Dutch neighbours, something that I could not easily reconcile with what I and other Americans 'knew' about the state-that it had been, and was, a great friend and protector of its Jewish residents. Trying to puzzle out where that notion came from, I hit on the role that Anne Frank's diary - the book, but also its theatre and film versionsplayed in shaping American Jews' images of Holland. The diary focused on the role of those who sustained the Frank family and others hiding from the Nazis over many months, at risk to their own lives. At the same time, however, it diverted attention from the fact that a Dutch person revealed them to the authorities, leading to the murder in the BergenBelsen concentration camp of all but Anne's father. I entitled my essay on this exploration 'The Anne Frank myth' (Yanow 2000). To my utter astonishment and horror, I discovered around 2007 that the title had been taken up by Neo-Nazis as evidence supporting their claim that the Third Reich's 'plot' to eliminate the Jewish people was a mythic invention perpetrated by ... whomever. Not only is meaning indeterminate, then, but myth-creators and -users have no control over how their intended meaning(s) will be read by others.

Myth can be a useful concept not only in analysing societal, policy, and organisational settings, but also in interrogating academic discourses. There, myths enable the perpetuation of theories that have been successfully challenged by other theories and which therefore should have been relinquished, but as they continue to do some sort of persuasive explana- 
tory work for some portion of that epistemic community the latter are not prepared to give them up. The example that comes most readily to hand is the continued belief in the unity of science, in falsifiability, in the possibility of objective knowledge from outside the study of human actsall those ideas that are the heritage of logical positivist and neo-positivist thinking, which continue to bedevil various political science practices. For a current example, see Jeffery Isaac's (2015) editorial arguing against the implications of those ideas for journal practices. To take another example, to the extent that there is also a creation myth for IR, as this volume's editor argues (see Bliesemann de Guevara, Chap. 1), it most likely persists not only 'despite' evidence to the contrary, but because it does presumably important, or possibly even necessary, work for the discipline, perhaps including bracketing further inquiry that might reveal IR to be naked in some sense, like the emperor parading around without clothes. But as Vickers (n.d.) pointed out with respect to the emperor parading around without clothes, there are times when the crowd needs to believe that their naked ruler is fully clothed, contrary visual evidence notwithstanding.

This is also the downside of myths' work: they are a conservative enterprise, standing in the way of new thinking and social change until the collective is more ready to contemplate it and act accordingly. Consider the civil rights movement in the USA: the myth of the colour line-attributions of negative behavioural and cognitive traits to African Americans and other Americans of perceptually non-European heritage-preserved the status quo, diverting attention from social injustices and constitutional violations, and preventing change; opposition, and consensus around it, grew over time, but their articulation-which fundamentally challenged entrenched ways of doing things - entailed countless physical beatings and loss of life. Making explicit the tacit knowledge underpinning political and other myths, then, is not always without cost.

What are we to make of this book's notion that myths are very real elements of, and indeed central to, contemporary life? The idea, the very language, poses a challenge to the emotionless reason and 'objectivity' that are understood to be the hallmarks of science. Here is where the methodological orientation of interpretive inquiry comes into play, given its central tenet that 'expressive' dimensions of human experience, including myths, are as central to social and political life as rational planning and policy-making, and that these can be studied 'scientifically' even when encompassing not only 'facts', but values (e.g. Rabinow and Sullivan 
1985/1979; Polkinghorne 1983; Hiley et al. 1991; Yanow and SchwartzShea 2014; Bevir and Rhodes 2016).

The concept of myth has, of course, an ancient history in the study of literature. Consider the Greek and Roman mythologies, of which Edith Hamilton, for instance, wrote. Anthropologists brought a parallel concept to the study of contemporary cultures, studying, for example, the mythical traditions of the Navajos or the Hindus. As interesting as these narratives are, however, they have the effect of exoticising 'myth', suggesting that it is something long ago or far away. Moreover, their anthropological-literary treatment features the story character of myths. Stories and narratives and their telling are surely one form of myth. Yet the idea of myth that many of the chapters here explore is not coeval with Hamilton's Greek and Roman myths, or the myths and mythologies of American Indian tribes that so captivated early generations of anthropologists (on one version of this disciplinary history, see Cowan et al. 1986). Those myths are clearly stories, and they were often recited on ritual or ceremonial occasions.

The sorts of myths engaged in this book-political, organisational, societal-are infrequently storied. Such myths may have no plots; no characters to be developed; no climaxes and resolutions, nor even beginnings, middles, and ends, as so much of the story-telling and narrative methods literature requires, following an Aristotelian approach (see Shenhav 2015,14 , for an argument against that definition, given that we often do not know how political 'stories' will end). Consider, for example, what I would posit is a societal myth well entrenched in the state where I currently live: 'The Netherlands is a tolerant society.' So much evidence has emerged from the morass of silence, which contradicts this reputed tolerance-from the recovery of the state's neglected history of slavery, to the acknowledgement of its active role in helping the Nazis to round up Jews and others for transport to concentration camps and certain death, to the demonization of darker-skinned Dutch, including those from Antillean and other backgrounds, which carries over into daily life from the annual embrace of St. Nicholas' helper Zwarte Piet/Black Pete-all of which contradicts this reputed tolerance. The tolerance myth, as I will call it, is a simple statement, not a story, not even an argument. It asserts a truth. And in that assertion, it stops further inquiry into, and discourse concerning, the intolerance embedded in celebrating, annually, ritually, the racialised character of the white-skinned Netherlander putting on the black-face of the slave. In this sort of analytical view of myths and the work they do for collective life, such ritualised acts - those put into practice repeatedly, on 
regularised occasions - are seen as the manifestations of the ideas that their associated myths embody.

These sorts of myths can block critical reflection into aspects of social, political, or organisational life for which public consensus does not (yet) hold. A simple statement-'Our goals are ... '-can keep inquiry at bay, thereby promoting the surface calm. Its form is neither reasoned argument nor narratively delivered story. Theoretically distancing myths not only in time and space but also in structural form work to ghettoise the concept, keeping us from seeing the work that myth can do in contemporary social, political, and organisational life and removing it from treatment in fields of study other than literature and anthropology.

Some might argue that we should get rid of myths - that they are antirationalist, perhaps even anti-scientific (or anti-science). This seems to me to parallel the Aristotelian or more recent Davidsonian arguments concerning metaphors: figures of speech that 'merely' decorate language that without them would be transparent, clear, and concise-and closer to the reasoned discourse of science. However, we do not, in fact, live in a technical-rational world, and, much like Monsieur Jourdain in Molière's play Le Bourgeois Gentilhomme, we speak in metaphors all the time, as Lakoff and Johnson (1980) have amply demonstrated - including in our scientific writings and speakings (on this point, see e.g. Brown 1976; Gusfield 1976; McCloskey 1985, 1994; Miller 1985, 1992; Schon 1979). QED—quod erat demonstrandum - then, with respect to the relative commonplaceness of myths.

Why do myths persist? Because consensus concerning what the myth masks is not yet sufficient, and because of a widespread fear that 'speaking truth to power' (to borrow policy analyst Aaron Wildavsky's book title) will reveal the societal cracks that belief in that myth works to plaster over. 'Myth' need not mean 'false belief' in an ideological, consciousness-raising sense. The concept has been theorised, too, in (structural-) functionalist ways, but it need not be. To ask what work myths do may serve similar ends, although that approach shifts the ontological terrain (reinterpreting and reframing the meaning of 'function'). We need more systematic work thinking through the relationships between 'myth' and 'narrative', exploring the framing work that myths accomplish, and investigating the conceptual links and distinctions between myths and other framing devices, such as metaphors and rituals. That the concept has analytic purchase, even power, is attested to by the empirical research presented in the chapters in this book, some of which build on the approaches sketched out 
here, others of which develop other lines of thought. These several chapters move the project of myth theorising and analysis further in these and other important directions. They should inspire other theorists of contemporary human life to examine the concept's utility for other settings and other avenues of inquiry.

Dvora Yanow

\section{BIBLIOGRAPHY}

Bevir, M., \& Rhodes, R. A. W. (Eds.). (2016). Routledge handbook of interpretive political science. New York: Routledge.

Brown, R. H. (1976). Social theory as metaphor. Theory and Society 3, 169-197.

Cowan, W., Foster, M. K., \& Koerner, K. (Eds.). (1986). New perspectives in language, culture, and personality: Proceedings of the Edward Sapir Centenary Conference (Ottawa, 1-3 October 1984). Amsterdam: John Benjamins.

Gusfield, J. (1976). The literary rhetoric of science: Comedy and pathos in drinking driver research. American Sociological Review 41, 16-34.

Haney-López, I. (2014). Dog whistle politics. New York: Oxford University Press.

Hiley, D. R., Bohman, J. F., \& Shusterman, R. (Eds.). (1991). The interpretive turn. Ithaca, NY: Cornell University Press.

Isaac, J. C. (2015). For a more public political science. Perspectives on Politics $13(2), 269-283$.

Lakoff, G., \& Johnson, M. (1980). Metaphors we live by. Chicago: University of Chicago Press.

McCloskey, D. N. (1985). The Rhetoric of economics. Madison: University of Wisconsin Press.

McCloskey, D. N. (1994). How to do a rhetorical analysis of economics, and why. In R. Backhouse (Ed.), Economic methodology (pp. 319-342). London: Routledge.

Miller, D. F. (1985). Social policy: An exercise in metaphor. Knowledge 7(2), 191-215.

Miller, D. F. (1992). The reason of metaphor: A study in politics. New Delhi: Sage.

Polanyi, M. (1966). The tacit dimension. New York: Doubleday.

Polanyi, M. (1967). Sense-giving and sense-reading. Philosophy 42(162), 301-325.

Polkinghorne, D. E. (1983). Methodology for the human sciences. Albany: SUNY Press.

Rabinow, P., \& Sullivan, W. M. (Eds.). (1985). Interpretive social science (2nd ed.). Berkeley: University of California Press.

Safire, W. (2008). Dog-whistle politics. In Safire's political dictionary (Rev. ed., p. 190). New York: Oxford University Press. 
Schon, D. A. (1979/1993). Generative metaphor: A perspective on problem-setting in social policy. In A. Ortony (Ed.), Metaphor and thought (pp. 254-283). Cambridge: Cambridge University Press.

Shenhav, S. R. (2015). Analyzing social narratives. New York: Routledge.

Vickers, S. G. (n. d.). The parable of the Emperor's Clothes, according to Sir Geoffrey Vickers. Unpublished lecture, Division for Study and Research in Education, MIT, Cambridge, MA.

Yanow, D. (1992). Silences in public policy discourse: Policy and organizational myths. Journal of Public Administration Research and Theory 2(4), 399-423.

Yanow, D. (1996). How does a policy mean? Interpreting policy and organizational actions. Washington, DC: Georgetown University Press.

Yanow, D. (2000). The Anne Frank myth. Judaism 49(2), 183-188.

Yanow, D., \& Schwartz-Shea, P. (Eds.). (2014). Interpretation and Method (2nd ed.). Armonk, NY: ME Sharpe. 


\section{Contents}

1 Introduction: Myth and Narrative in International Politics I Berit Bliesemann de Guevara

Part I Theoretical and Methodological Foundations

2 Myth in International Politics: Ideological Delusion and Necessary Fiction

Berit Bliesemann de Guevara

3 Beyond National Policymaking: Conceptions of Myth in Interpretive Policy Analysis and Their Value for IR Sybille Münch

4 The Precipice of Myth: Mythology/Epistemology 67 Robert Cooke

5 Bringing Claude Lévi-Strauss and Pierre Bourdieu Together for a Post-structuralist Methodology to Analyse Myths Catherine Goetze 
6 How to Study Myths: Methodological Demands and Discoveries

Franziska Müller

Part II Empirical Explorations

7 Warlords and States: A Contemporary Myth of the International System

Catherine Goetze

8 Afghanistan and the 'Graveyard of Empires': Blumenberg, Under-complex Analogy and Basic Myths in International Politics

Florian P. Kühn

9 Mutually Implicated Myths: The Democratic Control of the Armed Forces and Militarism Katharine M. Millar

10 Tales and Images of the Battlefield in Contemporary Warfare

Alastair Finlan

11 The Powerful Myth of the International Community and the Imperative to Build States

Katarzyna Kaczmarska

12 Global Governance and the Myth of Civil Society Participation

Charlotte Dany and Katja Freistein

13 Myths of the Near Future: Paris, Busan, and Tales of Aid Effectiveness

Franziska Müller and Elena Sondermann 
14 Organising Babylon: The Coordination of Intervention and the Denial of Politics

Stephan Hensell

Part III Reflections

15 Mythography: No Exit, No Conclusion?

Michael Loriaux and Cecelia Lynch 



\section{Notes on Contributors}

Berit Bliesemann de Guevara is a senior lecturer at Aberystwyth University's Department of International Politics, UK. Previously she held positions at Bremen University and Helmut Schmidt University Hamburg. Her current research explores ways of knowledge production in conflict and intervention politics. Her projects focus on transnational think tanks, transfers of evidence and expertise across science, justice and politics, fieldwork methodologies in intervention contexts, remote data gathering on conflict, urban legends of intervention, politicians' field visits and, not least, myths in international politics. She has also worked on international statebuilding, armed conflicts, and political charisma.

Robert Cooke holds a master's degree in critical international relations from the Department of International Politics at Aberystwyth University, UK, having previously studied history and politics at the University of Sheffield. His main research interests revolve around deconstruction and postmodern philosophies, as well as a number of interrelated topics including questions on the subaltern and on silences, which in this case help inform the basis of his approach to mythography, and the role of myth in knowledge production. He plans to work towards a $\mathrm{PhD}$ in the near future.

Charlotte Dany is a research fellow and lecturer at the Chair of International Relations and World Order, Goethe University Frankfurt, Germany. She holds a $\mathrm{PhD}$ from Bremen University and graduated from Free University Berlin. Her main research interests include the role of INGOs, global governance and the politics of humanitarian aid. She published a research monograph on NGOs and global governance with Routledge in the Rethinking Globalizations Series as well as articles in Global Governance and Zeitschrift für Internationale Beziehungen. 
Alastair Finlan is a reader at the Department of International Politics, Aberystwyth University, UK. Previously, he worked at Keele, Plymouth, the American University Cairo and the Britannia Royal Naval College. His research includes military culture, Special Forces and the Global War on Terror. Among his monographs are Contemporary Military Strategy and the Global War on Terror: US and UK Armed Forces in Afghanistan and Iraq 2001-2012 (Bloomsbury, 2014), Contemporary Military Culture and Strategic Studies: US and UK Armed Forces in the 21st Century (Routledge, 2013) and Special Forces, Strategy and the War on Terror: Warfare by Other Means (Routledge, 2008).

Katja Freistein is a senior researcher in international relations, formerly at the Collaborative Research Centre/SFB 882 at Bielefeld University, and now as Head of Research Unit 1 at the Centre for Global Cooperation Research, University of Duisburg-Essen, Germany. She holds a PhD from Goethe University Frankfurt and graduated from the University of Münster. Her current work and publications are concerned with global inequalities, international political sociology and international organisations, with a particular focus on the World Bank and UNDP.

Catherine Goetze is a senior lecturer at the Department of International Relations, University of Sussex, UK. Her research has focused in recent years on the sociology and culture of international peacebuilding, most notably of United Nations (UN) peace missions. She has published widely on peacebuilding, cosmopolitanism and various aspects of peacebuilding culture. She has just finished a book project on the social and professional field of international peacebuilding, in which she scrutinises the social, professional, educational and cultural backgrounds of 'peacebuilders' who work for the UN, international agencies, non-governmental organisations, non-profit consultancies and think tanks in post-conflict settings.

Stephan Hensell is a senior researcher in the Working Group on the Causes of War and at the Institute of Political Science, Hamburg University, Germany, where he is doing research on intervention, peacebuilding and civil wars. From 2009 to 2010 he was a visiting research fellow at the Department of Politics and International Relations at the University of Oxford, and from 2000 to 2005 researcher at the Institute for Peace Research and Security Policy at the University of Hamburg.

Katarzyna Kaczmarska is a post-doctoral fellow at Aberystwyth University's Department of International Politics, UK. She holds a PhD from Aberystwyth and is a graduate of the School of Oriental and African Studies, University of London. Her $\mathrm{PhD}$ thesis engaged critically with knowledge production on the international, exploring the idea of international society and contrasting Russian views of international politics. Her research interests include paradigms within academic work on International Relations and their links to the practice of international relations. Previously, she worked as research and teaching fellow at the OSCE Academy 
Bishkek and analyst and policy practitioner in development cooperation. She has published on Central Asian borders, security and development politics.

Florian P. Kühn is a senior lecturer at Helmut Schmidt University Hamburg, Germany. He has published on risk, security and development in South and Central Asia and on the narrative foundations of interventionism in journals including International Peacekeeping, International Relations, Canadian Foreign Policy Journal, Peacebuilding, and Zeitschrift für Außen- und Sicherheitspolitik. His monograph Security and Development in World Society (2010, in German) was awarded the German Middle East Studies Foundation's dissertation award. He also edited The Politics of Intervention: The Tyranny of Peace (Routledge 2016) with Mandy Turner, and is co-editor of Journal of Intervention and Statebuilding.

Michael Loriaux is Professor of Political Science at Northwestern University, USA. He is the author of European Union and the Deconstruction of the Rhineland Frontier (Cambridge University Press, 2008) and Europe Anti-Power (Routledge Interventions series, forthcoming 2016).

Cecelia Lynch is Professor of Political Science at the University of California, Irvine, USA. Her publications include Beyond Appeasement: Interpreting Interwar Peace Movements in World Politics (Cornell, 1999), which addresses mythological narratives in IR and won the Myrna Bernath and the Edgar Furniss Prizes, Strategies for Research in Constructivist International Relations with Audie Klotz (Routledge, 2007), and Interpreting International Politics (Routledge, 2014), and many articles and chapters on religion, ethics, humanitarianism and interpretive methodologies in IR.

Katharine M. Millar is a DPhil candidate at Somerville College, University of Oxford, UK. Her doctoral dissertation examines popular discursive constructions of the military in the USA and the UK, and the way they both challenge and inform processes of collective subject-formation in international relations. Her research interests include civil-military relations, gender and the military, the standard of civilisation, the politics of remembrance and commemoration, and the overarching connection between liberal subjectivity and political violence. Prior to commencing her doctorate, she was a policy researcher at the legislative assembly in Alberta, Canada.

Franziska Müller is an assistant professor at the Department of Social Sciences, Kassel University, Germany, where she coordinates a Junior Research Group on global/local energy transition governance. Her research interests are international relations (constructivist, poststructuralist and postcolonial approaches) and global governance, especially governmentality and global environmental governance. Her PhD thesis focused on EU-ACP relations and analysed the change of this postcolonial relationship as a change of governance and normative power. Previously she was based at TU Darmstadt, where she coordinated the VW-funded 
research project 'Challenges of European External Energy Governance with Emerging Powers', together with Michèle Knodt and Nadine Piefer.

Sybille Miunch is Professor for Theory of Public Policy at the Center for the Study of Democracy, Leuphana University Lüneburg, Germany. Her research focuses on interpretive approaches to policy analysis as well as urban and migration research. She has worked widely on the methodology of interpretive policy analysis and its post-empiricist epistemology in general and discourses in the field of immigrant housing and integration in particular. Her latest cross-national work focused on the role of storylines and narratives in constructing urban problems. She is the author of a German-language course book on interpretive policy analysis (Springer VS, 2015).

Elena Sondermann is a researcher at the Institute for Development and Peace, University of Duisburg-Essen, Germany. She has published on global governance, international development cooperation and foreign aid. She is specifically interested in theorising the nature of cooperation (e.g. as gift giving), understanding the narratives and myths that dominate the field, and interpreting the relationships and practices of national and international development organisations. Her PhD thesis analyses the role of the British aid agency DFID, asking how its reputation, position and relationships with other actors have changed as a consequence of embedding British aid in a broader foreign policy tradition.

Dvora Yanow is a guest professor at Wageningen University's Department of Social Sciences. Her research and teaching explore the generation and communication of knowing and meaning in policy and organisational settings. Present research includes state-created categories for race-ethnic identity, immigrant integration policies and citizen-making practices, research regulation (ethics committee) policies, practice studies, and science/technology museum spaces and the idea of science. Her most recent book, Interpretive Research Design: Concepts and Processes, written with Peregrine Schwartz-Shea, is the first volume in their coedited Routledge Series on Interpretive Methods; their co-edited Interpretation and Method: Empirical Research Methods and the Interpretive Turn has been published in a second edition. 


\section{List of Figures}

Fig. 2.1 Conceptualisations of 'myth'

Fig. 7.1 Publications with 'warlord' in the title, keywords or abstract per year (Scopus count)

Fig. 7.2 Publications with 'warlord' in the title, keywords or abstract per country (Scopus count)

Fig. 7.3 Functions and sequences of the warlord myth

Fig. 7.4 Functions and sequences of the state myth as opposed to the warlord myth

Fig. 7.5 Counts of 'warlord' in the headlines in USA newspaper publications, 2007-2012 ( $N=998)$ 



\section{List of TABLES}

Table 2.1 Socio-political functions of myth

32

Table 7.1 Giustozzi and Ullah on warlords in Afghanistan

Table 13.1 Core principles of the Paris declaration
137

254 